\title{
NCKAP1 Gene
}

National Cancer Institute

\section{Source}

National Cancer Institute. NCKAP1 Gene. NCI Thesaurus. Code C138140.

This gene is involved in both lamellipodia formation and endocytosis. 